水文 - 水凟源学 会誌

J. Japan Soc. Hydrol \& Water Resour.

\begin{tabular}{ll} 
Vol. 6. No. 4 (1993) pp. 364-376 \\
\hline
\end{tabular}

\title{
カスピ海の水位変動
}

\section{On the Changes of the Caspian Sea Level}

\author{
森 広道* （気象庁観測部高層課） \\ Hiromichi MORI Japan Meteorological Agency, Aerological Division
}

\section{はじめに}

ロシアではユーラシア大陸における気候変化の 1 つのシグナルとして, カスピ海とアラル海の水位変 動の実況監視を行っており, その水位データがロシ アの科学技術専門誌 “気象と水文” 1991年 6 月号加 ら毎月の水文気象概況欄に揭載されるようになった。 カスピ海の水位デー夕は全地球的な気候変化のなか の僅か 1 つのデータにすぎないが, ユーラシア大陸 だけでなく他領域の気候変化との関連からも参考に なると思われる。

本解説文は, 気象庁長期予報課に事務局を持つ長 期予報研究グループ ( L . F グループ)が発行している “グロースベッター”誌の第 31 巻第 1 号に揭載され た「カスピ海の水位変動について」という紹介論文 をもとに，加筆修正したものである.

第 1 章ではカスピ海の水位変動の全体像を, 第 2 章ではロシアの最近の論文から, 気候変化に伴う河 川流量変化予湘等を紹介する. 本文中で引用した論 文は最後に参考文献として揭げているので, 詳紐は こちらを参考にしていただきたい。

\section{I . カスピ海を取り巻く全体佛}

\section{1. 周辺地城の状熊}

カスピ海は琵琶湖の約 550 倍の面積をもつ世界最 大の湖で, 最大水深995mは琵琶湖の約10倍である. カスピ海へはウラル川・エンバ川等のいくつかの河 川からの流入もあるが, 流入量の大半は東ヨーロッ パ平原中央部から流れるボルガ川（カスピ海への流入 量の約 $80 \%$ ）に依存している（図 1-1 a 、1 b ）。 カスピ海の湖面は海面より $28 \mathrm{~m}$ 低く，その塩分濃
度はカスピ海に流入するボルガ川等の淡水の影響て 平均海水の3分の1程度である. しかし，カスピ海の 東に位置するカラ・ボガス・ゴル湾（图一16中の “ $\mathrm{D}$ ” に相当する)ではこれに流入する河川はなく，塩分濃 度はカスピ海よりはるかに高くなっている。

カスピ海の隣カザフ共和国にあるアラル海・バル ハシ湖・イシクリ湖の水位が近年急速に低下してき ていることはよく知られている。例えば，アラル海

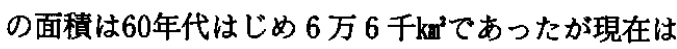
その 3 分の 1 に減り, 水位は $13 \mathrm{~m}$ 低下した。 また, 最 近10年間にバルハシ湖の水位は $2 \mathrm{~m}$ 下がり, イシク リ湖も $3 \mathrm{~m}$ 低下した。

このように，近年のカスピ海周辺の地域が経済的 要因 (人為的要因)に気候的要因 (干ばつ傾向) が重な り水位が低下しているという事実とは反対に，カス ピ海では上界傾向をたどっている，現在のところ， この水位上昇の直接原因についてははっきりとした ことはわかっていないが，農業用水・飲料水等の人 為的要因によるボルガ川からの流入量の減少を打ち 消すような大気現象が, カスピ海周辺で生じている と考えられている，その実態はどのようになってい るのであろうか。

\section{2. カスピ海周辺の水系及び水路}

本論のカスピ海の水位変動に入る前に, カスピ海 周辺の実態を見ておく(図一1).

カスピ海系地域は約 150 万 $\mathrm{km}^{2}$ の集水域を持ち,シべ リアの 3 大河川に次ぐボルガ川によって支配されて いる. 全長約 $2500 \mathrm{~km}$ の゙ルガ川は, その東岸の支流 であるカマ川とともにヨーロッパ平原の大部分とウ ラル山脈の西側面の水を南方へカスピ海へ向けて流 


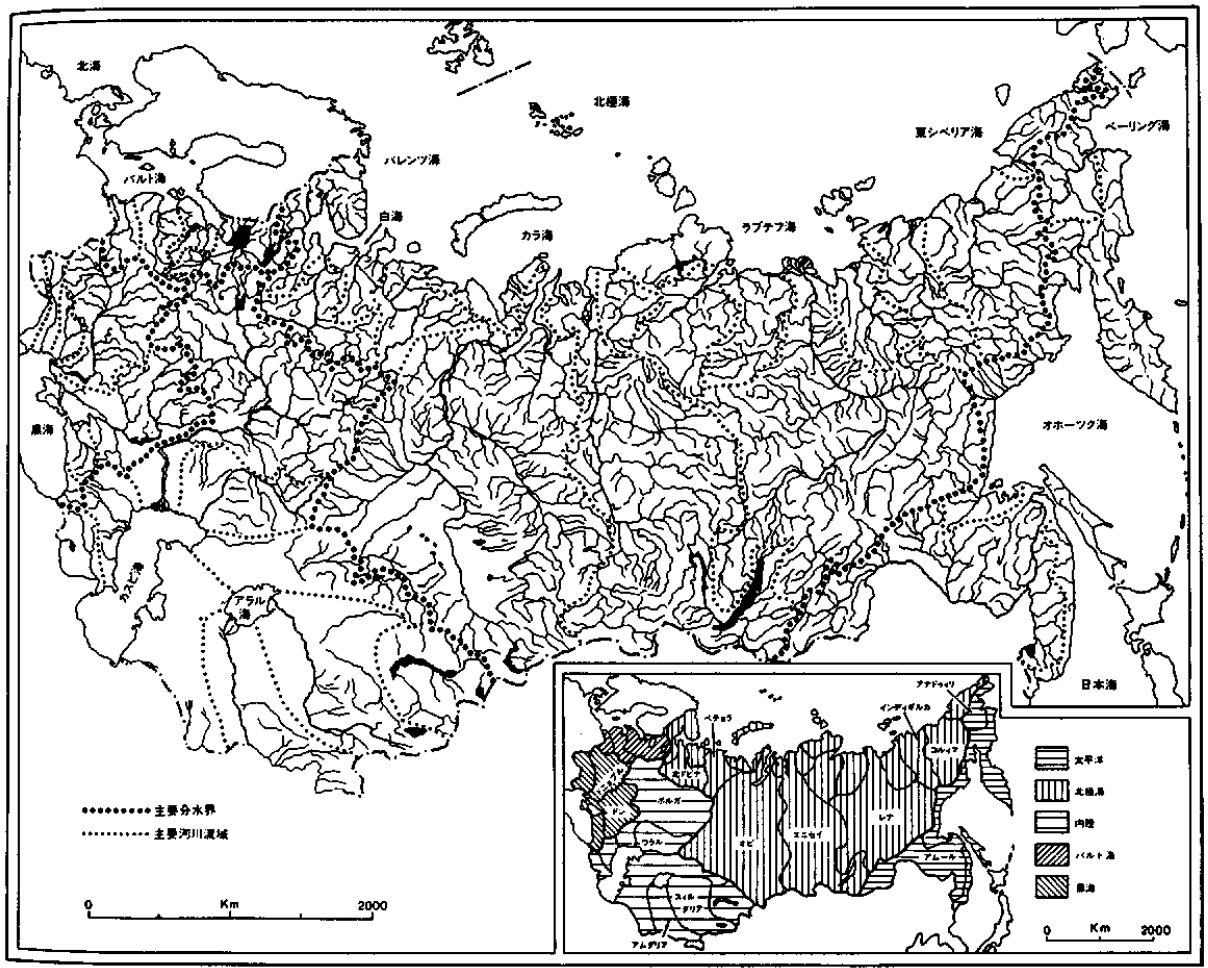

図一1 a カスピ海周辺の水系図

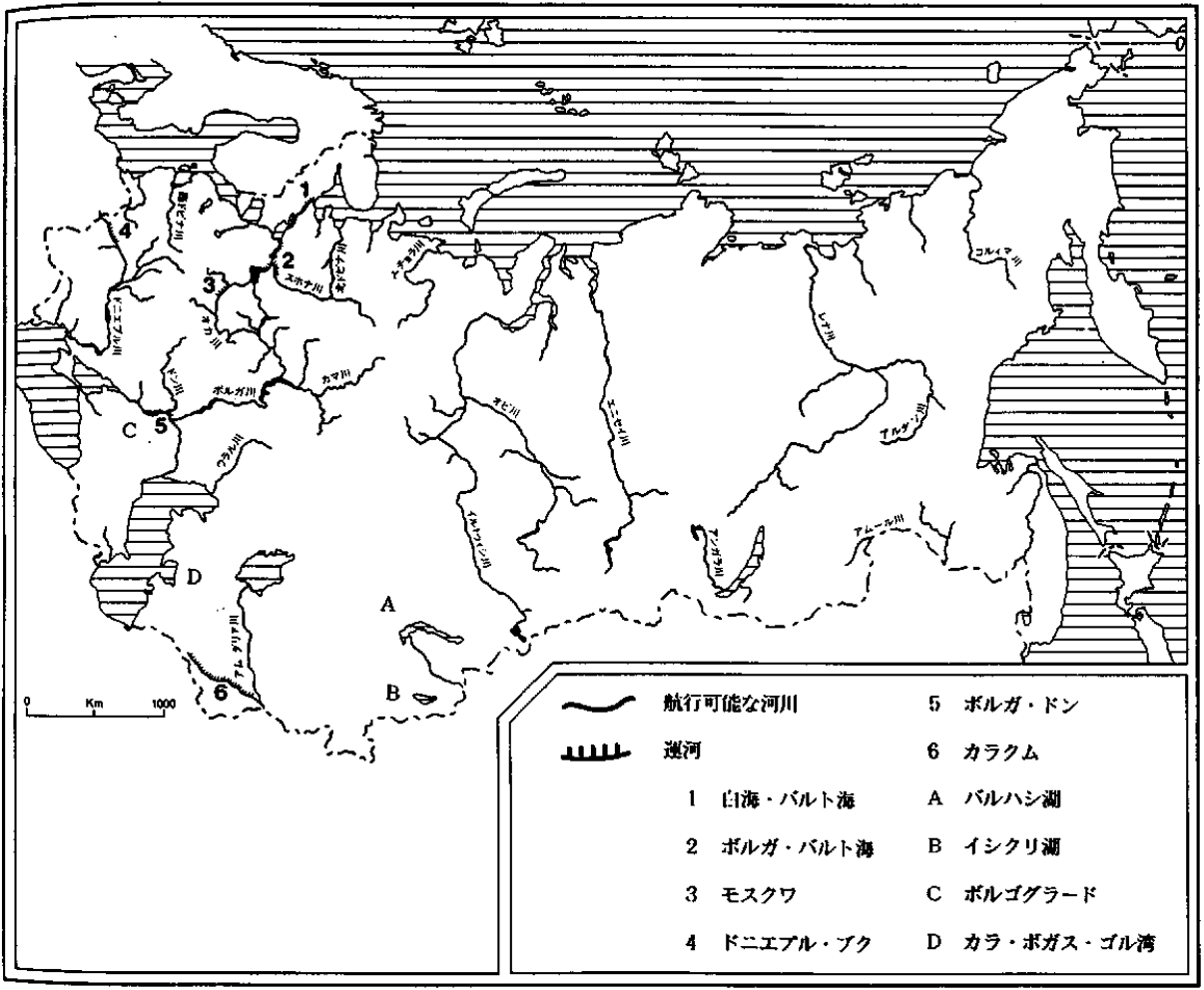

図一1 b カスピ海周辺の水路図 
している(图一1)。

ボルガ川は高度に発達した交通機関として, 貨物 輸送量の50〜60\%を担っているが, ボルガ川の機能 は運河の建設によってさらに重要性を増している。 例えば，1952年に完成したボルガ・ドン運河は東部 ウクライナとの接続とボルガ川・黒海間の連結を提 供し, また, カスピ海がザカフカスと中央アジアを つなぐ役割をはたしている。

また，カマ・ボルガ合流点から下流では，ボルガ 川は一連の水力発電用に塿止められた人工湖となり, 種々の水門によって流れを遅らせながら川の積載能 力を増大させている(図一1b).

\section{3. 水位帘怔}

カスピ海の水位変動については長期的な変動が調 べられている，過去 200 年間の水位変動は $4.5 \mathrm{~m}$ に達 し, 今期間の最高水位は1804〜1805年で, 最低水位 は1977年であった。

また，地質学的推定によると今から約 2 千年前の 水位は現在より $15 \mathrm{~m}$ 程度高かった。この高い水位は 次第に低下していき，5〜6世紀頃は現在よりも 3 $\mathrm{m}$ 程度低くなった. その後, 水位は次第に上昇し14世 紀頃には約 $10 \mathrm{~m}$ 程度高くなった。

1830 年より観測機器によるカスピ海の正確な水位 観測が始まった。そ実測值によると，ボルガ川の 水を灌がい用水に利用するなどの人為的要因が影響
し, 1830年から1930年までの100年間は約 $1 \mathrm{~m}$ 程度の 緩やかな水位の低下であったが，1930年から1970年 の 40 年間は約 $3 \mathrm{~m}$ の低下となった.

特に，1929年から1956年にかけては $2.4 \mathrm{~m} も$ 低下 （注：50年代は旧ソ連経済において“黄金時代”と呼ばれ た経済成長期に対応している)したため, 浅瀬の多い北 部の旧ソ連領を中心に漁村が内陸に取り残されたり， 港が使えなくなり社会問題化した。この低下は 1977 年を境にして上昇に転じ，現在まで水位の上昇が続 いている(团一2).

\section{4. 最近の水位变功}

上述のようにカスピ海の水位は1930年から1977年 まで低下し，この低下は3m以上に達したが, 図一2 ように1978年から現在(1991年)までカスピ海の水位 は上昇している. 1990年の平均水位- $27.57 \mathrm{~m}$ (以 下，水位は全て海面を基準）は1977年の水位よりも約 $1.5 \mathrm{~m}$ 高かった.

1990 年 7 月（月平均水位 $-26.98 \mathrm{~m}$ は 1990 年 6 月より も0.5m高い), カスピ海の水位はボルガ川への流入量 の増大により最大に達し,この水位は12月にかけて 僅か $7 \mathrm{~cm}$ しか低下しなかった。

図一 3 はロシア連邦水文気象委員会 (旧ソ連国家水 文気象委員会) 発行の水文気象概況欄の記事より, 1990年 9 月から1992年 9 月までのカスピ海の水位を グラフ化した図である.一般的に水位は顕著な年内

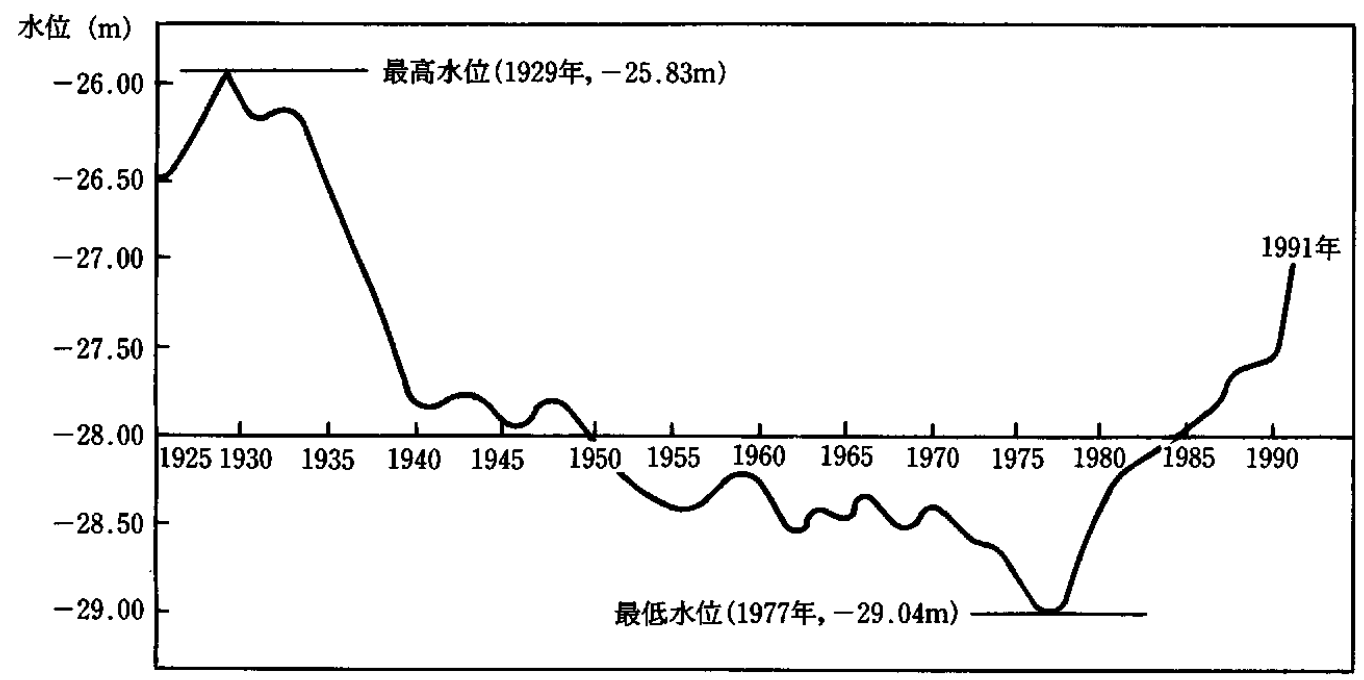

图一2 カスピ海の水位変勤の経年变化図 ${ }^{11} .1929$ 年の $-25.83 \mathrm{~m}$ と 1977 年のー $29.04 \mathrm{~m}$ がそれ ぞれ今期間中の最大値と最小值. 


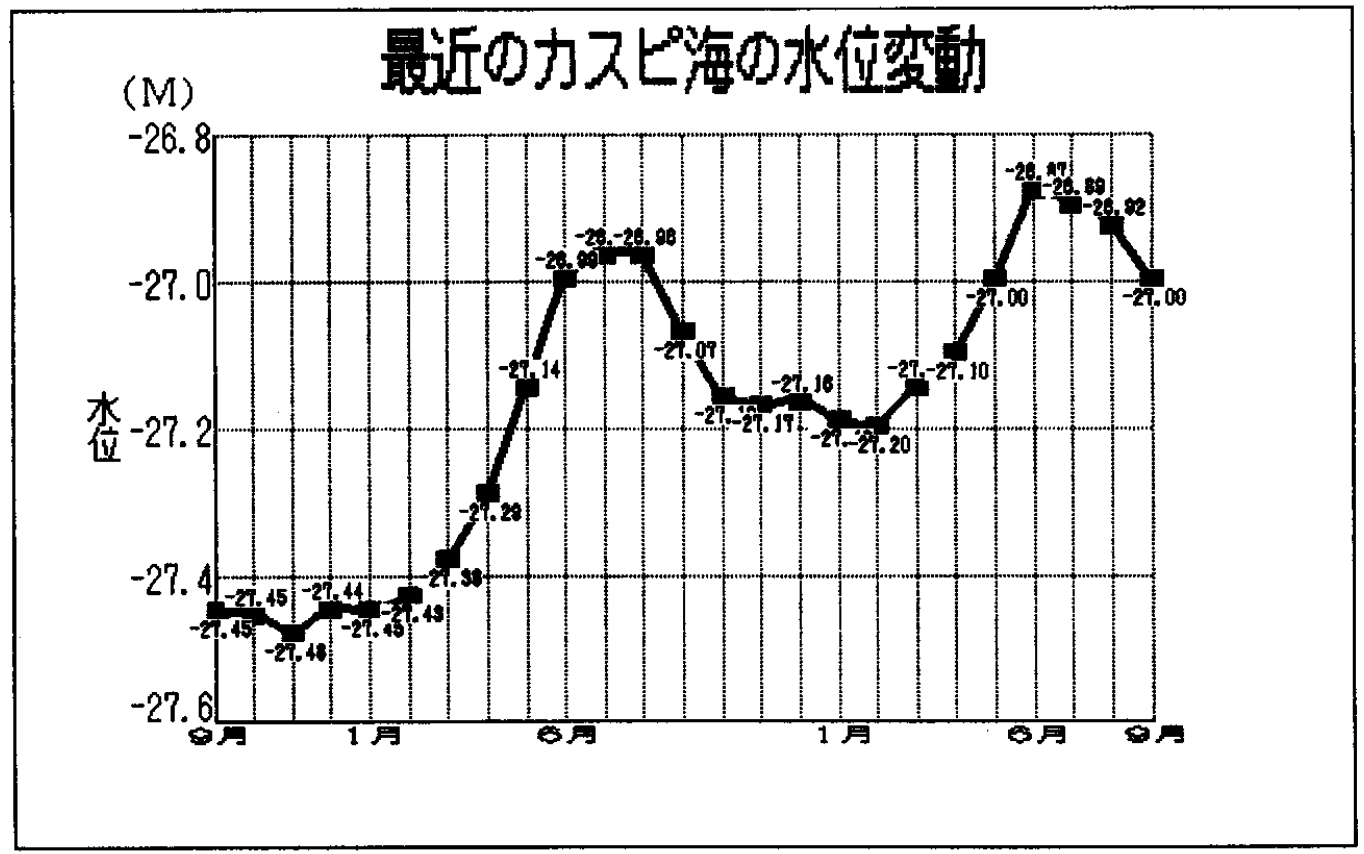

図一３ カスピ海の水位変勤（1990年 9 月から1992 年 9 月まで，“気象と水文”の各月の水文気 象概況欄上り).

変動を伴っている. 最高水位は $7 \sim 8$ 月, 最低水位 は12〜 1月で, 水位の季節変化は平均で $20 \sim 40 \mathrm{~cm}$ と なっている.

図一3によると，1991年 9 月から1992年 9 月の平 均水位 $(-27.06 \mathrm{~m})$ は前年の同時期よりもさらに 20.3 $\mathrm{cm}$ 高い.また，1992年の春先には，ボルガ川の河川 で氾濫と増水があった. 特に, ボルガ川の隣の流域 であるアゾフ海に注ぐドン川での春先の増水は, 最 近100年間では最も箃しいものであった。

また, 最近のカスピ海の水位上昇の特徴として, 強風の効果による水位上昇が加わり, 沿岸域の水位 が著しく高くなっていることがある.この結果, 沿 岸の地域によっては水位はすでに $1.0 \sim 1.5 \mathrm{~m}$ 上昇し, $30 \sim 40 \mathrm{~km}$ の距離まで水が浸水, 特にカスピ海の北部 で多くの被害が発生している模様である.

さらに，カスピ海の北東部においては水文気象観 測網が充分ではなく，そのことも強風による沿岸の 水位上昇の予測を困難なものとしているようである (注：ロシアの気象機関では地域によって若干異なるが, $15 \mathrm{~m} / \mathrm{s}$ 以上の風速が予想されると強風注意報が, $25 \mathrm{~m} / \mathrm{s}$ 以上の風速が予想されると強風警報が発令される).

\section{5. 水位上界の原因（その 1$)$}

一般的には，カスピ海の水位上昇の原因として次 の 4 つが挙げられる. (1)湖底の上昇 (2)雪解け水の 増水 (3)ボルガ川の水量の意図的操作 (4)1990年の イラン地震等, 周辺地域で地震の影響.

1991年 8 月, カスピ海とアラル海等での水位変動 の相違を, ソ連国家水文気象委員会とソ連水文気象 センターで担当官に質問する機会があった. Trenin B.A.旧ソ連国家水文気象委員会予報部長とVasiliev A.A.水文気象センター長はともに上記の上昇原因 のうち(2)を主張された。

両氏のカスピ海の水位上升のシナリオは,「カスピ 海の水位上昇は, ユーラシア大陸での 80 年代に入っ てからの高温, 特に冬季のヨーロッパロシアに扔け る気温の上昇によりその地域の融雪量が増加した。 増加した雪解け水がボルガ川を通ってカスピ海に流 入した結果，水位が上昇している，これに対して， カザフ共和国周辺では, 例えばアラル海の場合, 北 方には河川はなく，南方にあるアムダリア・シルダ リアという 2 大河川は中央アジア山岳地帯に流れて いる.」というものであった. 


\section{6. 水位上界の原因（その 2$)$}

Trenin B.A.旧ソ連国家水文気象委員会予報部 長のカスピ海の水位上昇に関する原因の要旨は以下 の通りである ${ }^{11}$.

1978年から1991年の水位上昇の主要原因は，カス ピ海への流入量の増加にある. 1970年から1977年に かけての水位低下時, カスピ海への平均流入量は年 間240 $\mathrm{km}^{3}$ であったが, 1978〜 1990年の水位上昇時に は年間 $307 \mathrm{~km}^{3}$ に増加した。

しかも，1980年にカラ・ボガス・ゴル湾を堰止め たこともカスピ海の水位を上げるのに寄与した。こ の影響で年間 $3 \sim 4 \mathrm{~cm}, 1980 \sim 1990$ 年の10年間で約 $35 \mathrm{~cm}$ 水位上昇があったと計算された。 カスピ海に おける水バランス計算では，流入量（主として河川等 からの流入量, 地下水からの流入量と流域ての降水量) と 流出量（主として湖面からの蒸発量とカラ・ボガス・ゴ ル湾への流出量) 汃ら推算し，1970～1977年の期間は 年平均水位でー14cm となった。一方，1978～1990年 は反対に年平均で+14cmであった。

このような, カスピ海での水バランスの平均値を 旧ソ連国家海洋大学と同水文大学が計算し, 以下の ような結論を出した。 その結果を衰一1に示す.

これによると，1970～1977年の水位の急激な低下 時にはカスピ海への流入量の減少と, 湖面からの蒸 発量の増加があった. 1978年からはカスピ海への地 表面流入量は急激に増加し，1990年は全観測期間で 2 番目の多さとなった。 1978～1990年平均では, 地 表面流入量はカスピ海の蒸発量とカラ・ボガス・ゴ ル湾への流出量より大きく, 平均 $52 \mathrm{~km}^{3}$ の流入量は年 間14cmの水位を上昇させることとなった。

70年代の平均では, カラ・ボガス・ゴル湾へのカ スピ海からの流出の結果，水位は年間 $1 \sim 2 \mathrm{~cm}$ 低下 した. 同湾は1980年にカスピ海から殹止められたが, 結果は反対に約 $3 \sim 4 \mathrm{~cm}$ の水位上昇を促すことと なった. 同湾による1980〜1990年の10年間の30〜 40 $\mathrm{cm}$ の水位上昇は, 同時期のカスピ海の水位上昇の約 $24 \%$ に相当する。

\section{7. 河川流量変化}

現在のカスピ海の水位上昇原因に，冬季の高温と 河川流量の増加があるというのがロシアの学者の結 論である，それでは，ューラシア大陸上の河川流量 はどのように変化しているのであろうか9.

図－4は1951〜1980年と1981〜1986年の旧ソ連領 における河川の年平均流量の変化図である．50年代 から70年代にかけては，東シべリア域を中心に流量 は多くなっているが, 旧ソ連西部のボルガ川・ドニ エプル川・ドン川流域では流量はマイナス傾向と なっている.

80年代に入ると全国的に流量は増加している，沿 ボルガ地方下流域やドン川に隣接したホペル川・ブ ズルク川等では流量はほとんど変化はないが，ボル ガ川上流・中流域の河川は 5 ３0\%増加し，ドニエ プル川とドン川流域では 3〜20\%増加している. ち なみに, アラル海周辺では南部を中心にマイナスと なっている.

旧ソ連の水文観測網の資料から1951〜1986年の年 平均流量の変動解析によると, 80 年代にトレンドの

表一 1 カスピ海の水バランス計算による各年の平均侸 ${ }^{11}$. 各年の平均量を上段 $\left(\mathrm{km}^{3}\right)$ と下段 $(\mathrm{cm})$

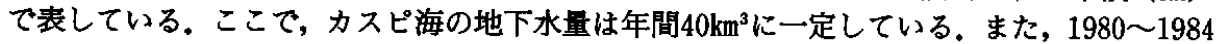
年のカラ・ボガス・ゴル湾へのカスピ海の流出量は, 同湾がカスピ海から堰止められたため にデータはないが，1985年からは年間約1.6k常で計算している.

\begin{tabular}{c|c|c|c|c|c|c}
\hline 期 間 & $\begin{array}{c}\text { 永位 } \\
\text { (产) } \\
\text { 海面基準 }\end{array}$ & 流 量 & 降水量 & 蒸発量 & $\begin{array}{c}\text { カラ゙ボガズ湾への流量 } \\
\text { 年 }\end{array}$ & $\Sigma$ \\
\hline $1900-1929$ & -26.18 & $\frac{332}{82.5}$ & $\frac{70}{17.3}$ & $\frac{389}{96.7}$ & $\frac{21.8}{5.4}$ & $\frac{-5.7}{-1.4}$ \\
$1930-1941$ & -26.80 & $\frac{269}{68.3}$ & $\frac{73}{18.5}$ & $\frac{395}{100.4}$ & $\frac{12.4}{3.2}$ & $\frac{-61.7}{-15.7}$ \\
$1942-1969$ & -28.18 & $\frac{285}{77.3}$ & $\frac{74}{20.0}$ & $\frac{356}{96.4}$ & $\frac{10.6}{2.9}$ & $\frac{-3.4}{-0.9}$ \\
$1970-1977$ & -28.64 & $\frac{240}{66.6}$ & $\frac{88}{24.3}$ & $\frac{375}{103.9}$ & $\frac{7.1}{2.0}$ & $\frac{-49.9}{-13.6}$ \\
$1978-1990$ & -28.08 & $\frac{307}{82.1}$ & $\frac{86}{23.0}$ & $\frac{343}{91.8}$ & $\frac{1.8}{0.6}$ & $\frac{52.2}{13.9}$ \\
\hline
\end{tabular}




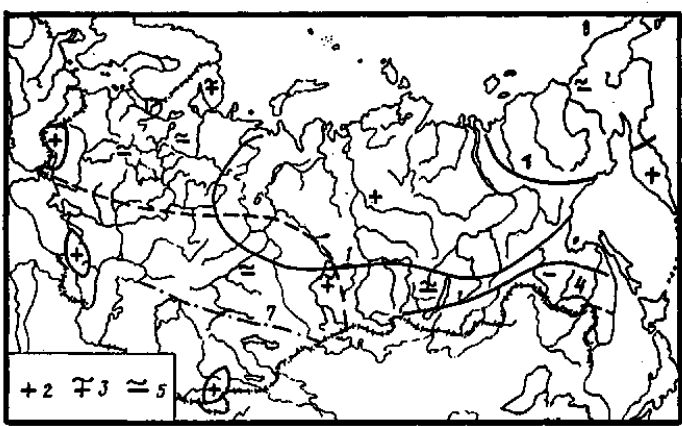

图一4 1951〜1980年と1981〜1986年の旧ソ連にお ける年平均流量の变化図". $1: 1951$ 1980年の流量変化の境界, $2: 1951 \sim 1980$ 年の流量変化がプラス域, $3: 1951 〜 1980$ 年の流量変化がプラスあるいは変化なしの 領域, $4: 1950$ 1980年の流量変化がマイ ナス域, $5: 1951$ 1980年の流量変化がマ イナスあるいは変化なしの領域, 6 : 1981 1986年の流量変化がプラス域の南限, $7: 1981$ 1986年の流量変化がマイナス域 の北限をそれぞれ示す。

変化 (增加) が生じている.

\section{8. ボルガ川下流域の状態}

旧ソ連の河川流量は全体として80年代に入ってか ら増加しているということである。しかし, 流量増 加の中心地域が北部であり，それらは北極海方面に 流入しているはずである.そこで 1.8 節では，具体 的にボルガ川下流域のボルゴグラード (図一 1 参照) 水力発電所での河川流量と,同水力発電所から約 200 $\mathrm{km}$ 下流にあるチェルニン・ヤルとベルフニェ・リ ビャージエ両水位観測所での水発生時期（初水の観 測時期)の資料，ボルゴグラード気象観測所での気象 解析資料を示す $(\text { 図一 5 })^{10)}$.

ボルジスキーやカムスキー等の多くの人工貯水池 が作られた1960年以降, ボルゴグラード水力発電所 の河川流出量は急増した。 1881年から1959年の期間 と比較すると，1960年から 1989 年は $42 \%$ の河川流出 量の増加となった。

ボルゴグラード気象観測所での11月から12月の平 均気温は，1960年以降は急激に上昇している，その 結果，1960年から1989年の平均気温は1881年から 1959 年の平均気温よりも $1.4^{\circ} \mathrm{C}$ 高くなった。

また, 河川流出量の増加と気温上昇によりチェル ニン・ヤルとベルフニェ・リビャージエの両水位観 測所での水発生時期は遅れてきた。1960年まではそ

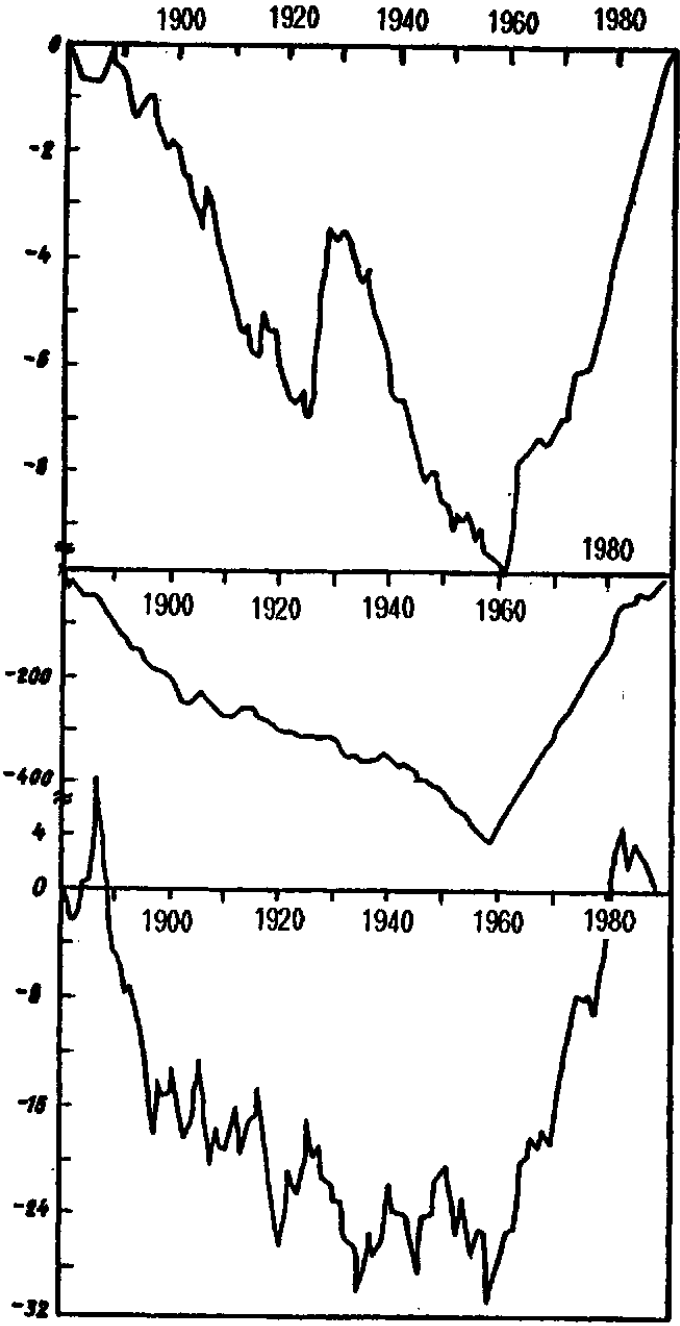

図一5 チェルニン・ヤル水位笅測所での河川流旦 (上段)と水発生時期 (中段),ボルゴグラー ド気象観測所での11月から12月の月平均気 温 (下段) の偏差の合計をそれぞれ示す ${ }^{10}$.

れぞれ11月25日と11月30日であったが，それ以降は 両観測所ともに12月17日となり，22日と17日遅く なった.

ボルガ川下流域における河川流量と気候変化が氷 の発生時期に影響していることが考えられる. 本解 析によると, 気候要因は承発生時期の変動の 35〜 45\%の寄与率になるということである.

80年代に入ってからの河川流量の増加をボルガ川 下流域の資料でも確認できるが，カスピ海の水位上 昇原因の 1 つとして，ロシア全土に約千ヶ所存在す 
ると言われる人工貯水池による流量調節の効果もや はり大きいと考えられる。

実際, カスピ海流域への河川からの流入量は人工 貯水池等により調整されている。しかし，それはカ スピ海の水位上昇速度を数 $\mathrm{cm}$ 下げただけで，気候変 化に起因する水位変動と対比することはできない, と言われる10,11).

\section{9. 政府機䦎の対応}

カスピ海の水位上昇は旧ソ連領だけではなく，周 辺地域の経済活動にも深刻な影響を及ほしてきてい る. 先に述べた湖北の都市での浸水等もあるが, 湖 南にあるイランでも深刻のようである。

イランからの報道によると, カスピ海の水位上昇 は13年前 (カスピ海の水位が上昇に変わった1978年相当 する)に始まり，年間13〜15cmずつ水位が上昇してい るという.これまでに $2 \mathrm{~m}$ 近くも湖面が高くなり,こ の一年間（1991年度）は特に上昇の度合いが著しく, 住宅が浸水したり世界の玲味キャビアの生産施設に 水が迫ったりしている，ということである。

緊急性を増してきたカスピ海の水位上昇を討議す るため, 1991年 6 月 $3 \sim 5$ 日, グーリエフ(カザフ共 和国南西部でカスピ海北部の都市) でカスピ海の問題 に関する全ソ会議が開催された。旧ソ連水文気象セ ンターの学者・専門家, 科学アカデミー, その他の 政府関係機関，カスピ海周辺地域の国民経済組織の 指導者が会議に参加した, 会議では, 水位上昇の原 因の解析と今後の変動予測, 治岸周辺地域の保護が 議題となった ${ }^{11}$.

カスピ海の水位変動では, 水位の長期変動予測が 問題となった。 その予測に対する責任は旧ソ連科学 アカデミーにあるが, カスピ海の水位予㴊の問題は 気温 ・降水量 - 雲量等の水文気象要因の超長期予測 を行うことにあるため, 参加した研究者は現在の科 学レベルでは $5 〜 10$ 年後の変動予測を正確に行うこ とはできない, と主張した。

一方, アゼルバイジャン・トルクメン・カザフス タンの各政府は急激なカスピ海の水位上昇の防止に 関し, 緊急援助供与を旧ソ連政府に求めた。旧ソ連 政府経済予測担当大臣は, 複合的に差し迫ったカス ピ海の水位上昇について，まず住民居住地・採油場・ 農業適地等の保讙について緊急な技術援助が必要な ことを強調し閉幕した。

\section{II . 気候予測}

\section{1. 気温・降水量予測}

第 2 章ではロシアの気候予測とカスピ海の水位変 動の長期予測を示す.

最初に, 図一6 はロシアの著名な気候学者Budyko M.I.の予想から，1951～1980年を平年値とした ときの1995〜2005年の地上気温偏差の時系列を示 す4).

1 は気温の年平均値, 2 は同 5 年移動平均値, 3 は予測の中間値，4 は予測の $50 \%$ 有意な幅をえれぞ れ示し, 北半球は上段である. 图一6によると, 2005 年にかけて南半球て気温が一定上昇するのに対して, 北半球では1990年末にかけて気温はやや低下するが, その後2005年にかけて上昇することが予想されてい る.

ここで用いられた予測モデルは，確率的相似群予 測手法 (probabilistic group-analogue forecast method）と呼ばれるもので, 本来二酸化炭素濃度の
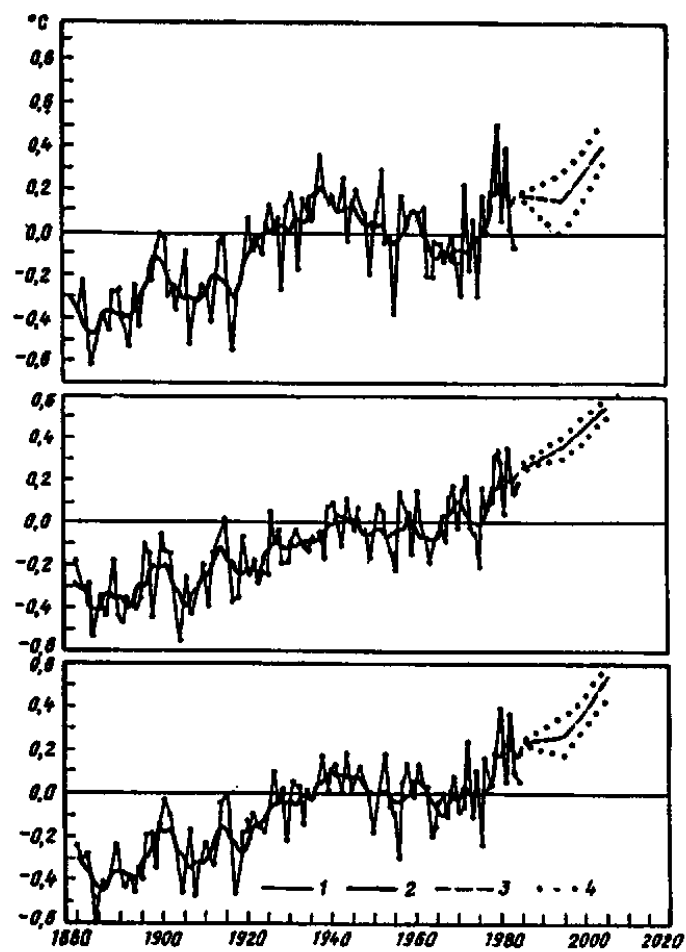

图一－1951〜1980年を平均値としたときの, 1995 〜2005年の地上気温偏差の時系列4). 上図 より, 北半球・南半球・全球をそれぞれ示 す (Budyko M.I.の予想加ら). 


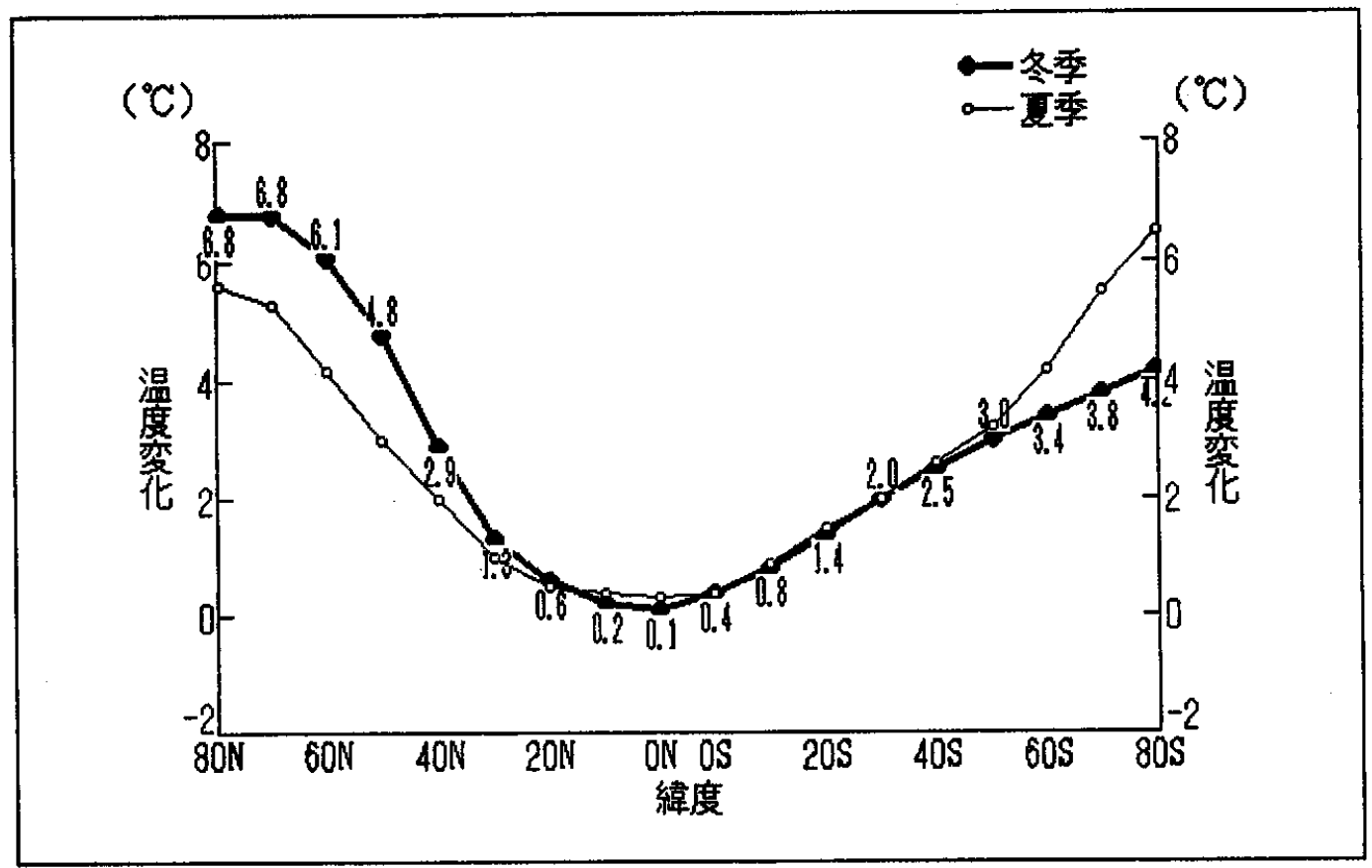

图一7最終間水期の気候最適期と現在との気温差 を冬季と严季で緯度別平均した図2).

増加を取り込んだ短期間の気候変化を予測するモデ ルであるが，このモデルを南北両半球と全球で走ら せ，1995〜2005年の地上気温が計算された。

ロシアに扔ける将来の気候予測については，大気 大循環の数値モデルによるシミュレーションよりも 類似法（注：古気候復元法で图一6もこれの応用だと思 われる)からのアプローチが中心である、それは,「気 候変動に関する政府間パネル (IPCC)」の第一作業部 会によるIPCCへの報告書（1990年 8 月）にあるよう に，ロシアが後者の中心であったことにもよると思 われる。

古気候復元に伴う不確実性には以下の要素がある が，西側の数值予測モデルと併合することによって 全体の予測精度が向上すると考えられる.

1 。過去の気候の復元に扔ける不確実性

2. 限られた空間領域の地球規模への拡張におけ る不確実性

3．過去の気候変化を引き起こした様々な要因の 相対的影響度の決定における不確実性

以下に示す解析例はほとんどが古気候復元から得 た資料が用いられている.

2.1節では人間活動等の人為的要因により, 例とし て2025年までに $2 \sim 3{ }^{\circ} \mathrm{C}$ 全球気温が上昇したとき
の古気候復元の事例を示す2).

時期は約 12 万 5 千年前の最終間氷期である. 過去 の気候復元 (気温と降水量)には, 主に海洋ではプラ ンクトンの分布を, 大陸では植物の分布を用い,こ れらと気候との間にある関係が数量化された。過去 の地勢とある地域に特有な気候の復元には, 岩石 学・古地理学・古植物学・土壤学・地質学その他の データが広範囲に用いられた。

最終間水期と現在との気温差の緯度別平均値を図 -7 に示す.全球気温は現在よりも $1.8^{\circ} \mathrm{C}$ 高かったよ うである. 高緯度で気温上昇が大きく, 北半球の 夏季の気温は現在よりも $1.5^{\circ} \mathrm{C}$, 南半球では $2.0^{\circ} \mathrm{C}$ 高 く, 北半球の冬季は $2.0^{\circ} \mathrm{C}$, 南半球では $1.8^{\circ} \mathrm{C}$ 高かっ た.

気温上昇の最大はシベリア北部 (冬季に $10 \sim 12^{\circ} \mathrm{C}$, 夏季に $\left.6 \sim 8{ }^{\circ} \mathrm{C}\right) \cdot$ ・ガ北部・グリーンランドに あった。西ヨーロッパや旧ソ連のヨーロッパ中央部 では夏季は現在より $1 \sim 2{ }^{\circ} \mathrm{C}$ 高く, 冬季は $3 \sim 4{ }^{\circ} \mathrm{C}$ 高くなり，年降水量は100〜 200 mm多くなった.

本解析では, 炭酸ガスやメタン等の温室効果気体 の役割がはっきりしておらず，また中・高緯度での 年代の不確実性が残る。しかし, 温暖化による雪氷 面積の減少は全球の熱的状態に影響を及ほすアルベ 
ド効果を上げ，さらに，温暖化のスケールに応じて 両半球の大陸での湿潤状態が改善されることが解析 されている.

\section{2. 流旦予測}

このような気温上昇が流量にどのように影響する のかに関して，図一8と图一 9 にはVinnikov K.R. とLemeshko N.A. 等の夏季の土壤水分含有量と年 平均流量の解析結果を示す ${ }^{3)}$.

これは将来の温暖化に伴って地球平均気温が 1 $\sim 2{ }^{\circ} \mathrm{C}$ 上昇したときの見積りである. 解析には古気 候资料より 2 つの暖かかった時代が用いられた。 1 つは地球の平均気温が現在よりも $1^{\circ} \mathrm{C}$ 高かった完新

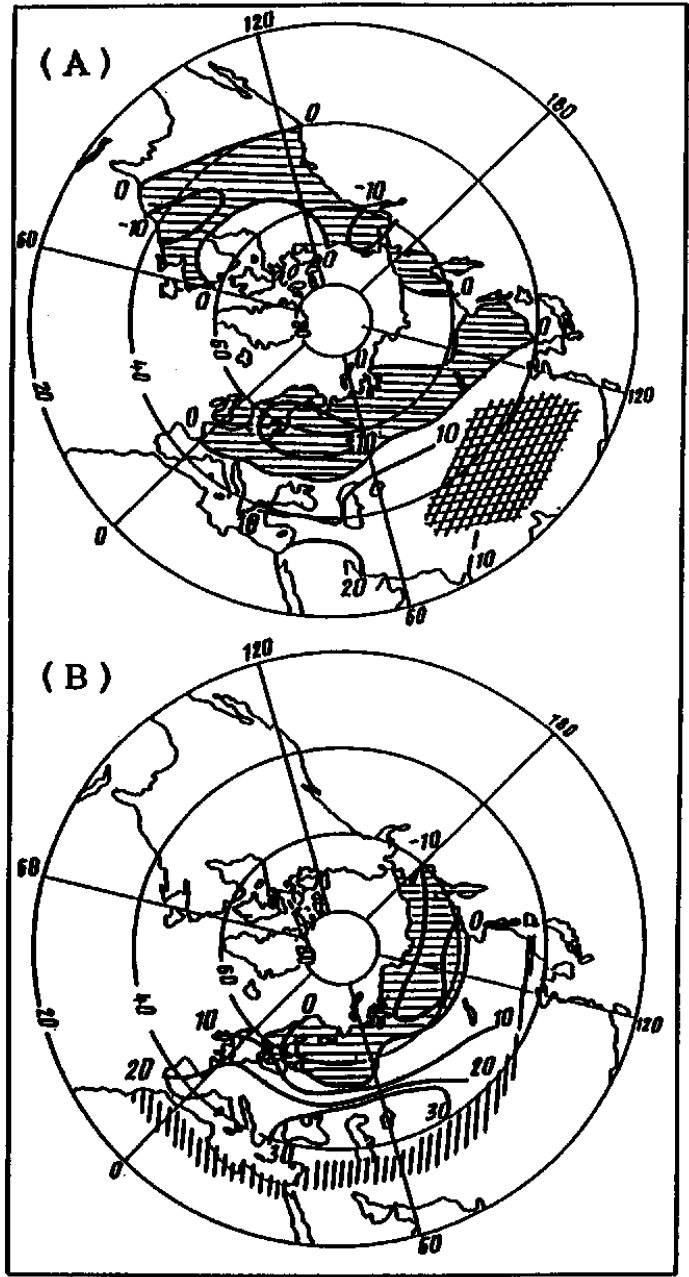

图一8 現在の更季の土壤水分含有量と比較したと きの変化図(\%)。(A)は完新世の気候最適期, (B)はミクリンスク間氷期をそれそれ示すs).
世の気候最適期 $(\mathrm{A}$ ：今から $5 \sim 6$ 千年前)であり，1 つは地球の平均気温が現在よりも $2^{\circ} \mathrm{C}$ 高かった最後 の間氷期であるミクリンスク間氷期 (B：今から 12 万 5 千年以上前) である.

解析手法としては，熱と水バランスに関する物理 方程式を用い, 土壤 $1 \mathrm{~m}$ 層の水分含有量・土地毎の含 水量の臨界値・蒸発率から蒸発量を求め, さらに降 水量と土壤 $1 \mathrm{~m}$ 層での土地の含水量効率等から年間 流量が計算された。土壤含水量の臨界值は植生と気 候条件により異なり，例えばツンドラ (凍土帯) やツ ンドラ草原では月平均気温が $10^{\circ} \mathrm{C}$ 以下の春秋では $170 \sim 200 \mathrm{~mm}$, 月平均気温が $10^{\circ} \mathrm{C}$ 以上となる夏季は 150 mmに設定された。

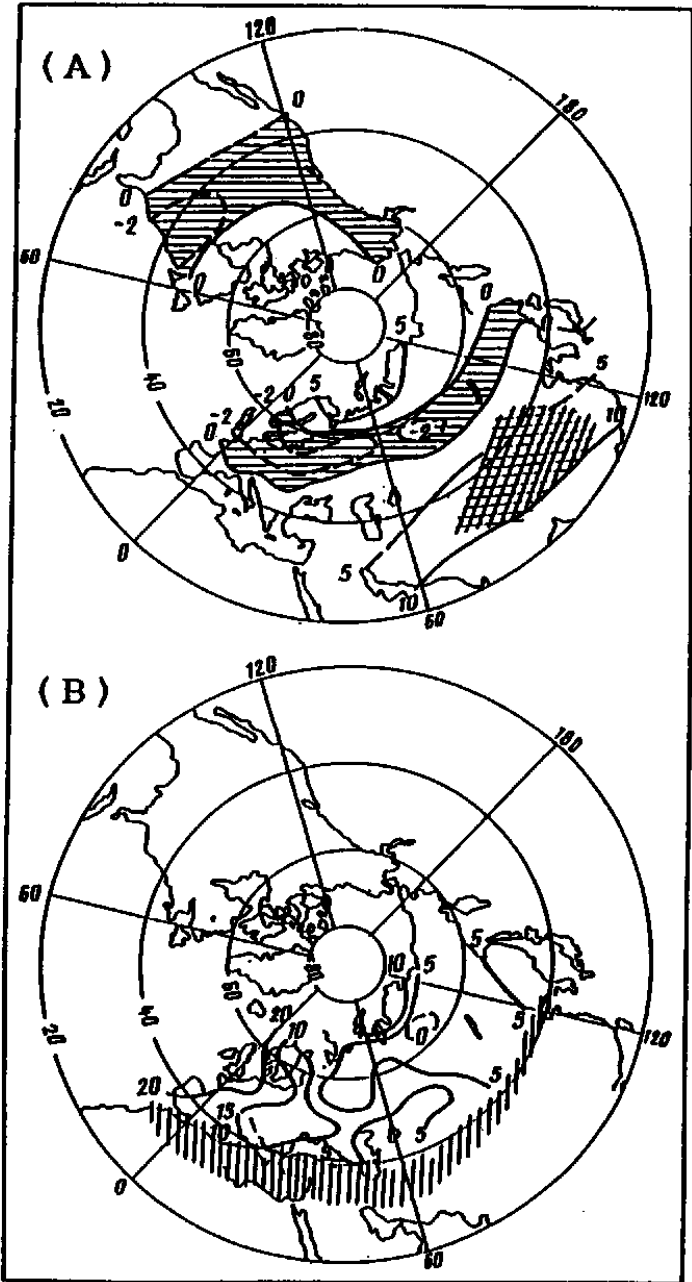

図一9 現在の年間流早と比較したときの变化図 (cm).（A)は完新世の気候最適期，(B)はミク リンスク間米期をそれぞれ示す3)。 
完新世の気候最適期の気候は, 温带地方ては土堙 水分含有量は現在よりも少なく, 北米の $40^{\circ} \mathrm{N}$ 以北の 領域とヨーロッパの $50^{\circ} \mathrm{N}$ 領域に減少するベルト の南限がある，土䁃水分含有量のより大きな減少は， ヨーロッパ北部と北米東部で10\%以上となり，これ は土壤 $1 \mathrm{~m}$ 層の水分量で $1 \sim 1.5 \mathrm{~cm}$ の隇少となった. ミクリンスク間水期では, 土壊水分含有量は $55 \sim 60^{\circ}$ N以北では滅少しているが，その滅少率は前者より も小さく領域も少なくなっている.ヨーロッパの森 林とステップ，その中間の地帯では10〜30\%土壌水 分含有量が増加している. 同地域の土壤 $1 \mathrm{~m}$ 層での水 分量が 2 2.5cm多かったことを示している.

完新世の気候最適期の年間流量は, ヨーロッパで は45〜 60 $\mathrm{N}$ の緯度帯で, 北米では $35 \sim 50^{\circ} \mathrm{N}$ の緯度帯 で減少しており，2３cm/年に達する．この地帯か ら南方と北方での年間流量の増加は, ヨーロッパと

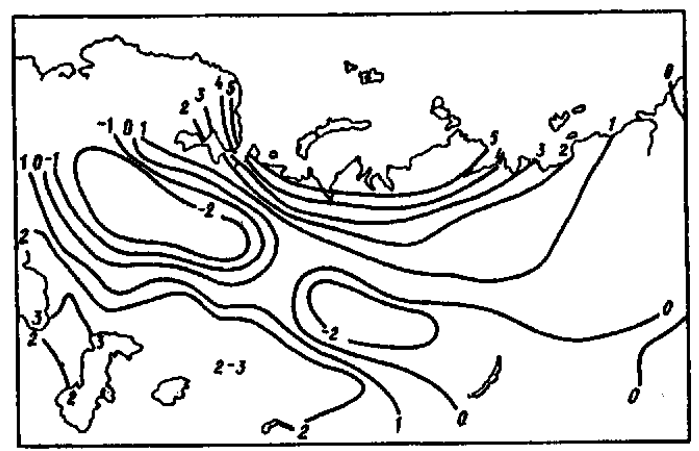

图一10 全球平均気温が現在より $1^{\circ} \mathrm{C}$ 上界したとき の旧ソ連領の河川の年平均流量变化図 ${ }^{12)}$ (単位はcm)。
アジアでは $5 \sim 10 \mathrm{~cm} /$ 年, 北米では $3 \sim 5 \mathrm{~cm} /$ 年とな る.より暖かかったミクリンスク間水期では, 年間 流量はアジアの砂漠地帯で $5 \mathrm{~cm} /$ 年,西ヨーロッパで 15～20cm/年と至るところで増加している.

图一10は, Vinnikov K.R.の2000〜2010年の全球 平均気温が現在よりも約 $1{ }^{\circ} \mathrm{C}$ 上昇したときの, 同時 期の旧ソ連領の河川の年平均流量の変化図である ${ }^{12)}$.

図一10には図一9の解析結果が参考にされている が,これらより気温の上昇が流量の増大となるのは 高緯度と穀倉地帯であることがわかる、ロシアの中 央部は東西に流量が減少することが予想されている。

\section{3. 気候带の变峌}

ロシア科学アカデミー地理大学・ロシア共和国家 水文大学・ロシア水文気象センターは, 主に蒸発量 と年間降水量を指標として, 温暖化に伴ったユーラ シア大陸上の気候帯の変化を 2 度グリッドで計算し た。その結果を表一 2 に示す5)。

現在, ツンドラと森林ツンドラ帯・針葉樹林帯は ユーラシア大陸の約 $60 \%$ を占めているが $1.4^{\circ} \mathrm{C}$ 気 温上昇で約 $22 \% に, 2.2^{\circ} \mathrm{C}$ 気温上昇で約 $14 \%$ に減少 することが予測されている.同様に，混合林・広葉 樹林・森林ステップ・ステップ帯は現在約 $27 \%$ を占 めているが, $1.4^{\circ} \mathrm{C}$ 気温上昇で約 $61 \%, 2.2 \%$ 気 温上昇で約 $65 \%$ となることがそれぞれ予測されてい る.

また，現在50〜 $55^{\circ} \mathrm{N}$ 帯にある針葉樹林帯の南限は $1.4^{\circ} \mathrm{C}$ 上昇することによって $60 \sim 65^{\circ} \mathrm{N}$ 帯に, $2.2^{\circ} \mathrm{C}$ 上 昇することによって $67^{\circ} \mathrm{N}$ 帯まで北上することが予 想されている。

\section{表一2 ユーラシア大陸の各気候带の特徴を示す文候要素と，各気候条件下での文候带の分布率予測 と解析值 $(\%)^{5)}$.}

\begin{tabular}{|c|c|c|c|c|c|c|c|c|}
\hline 気 & 帯 & $\begin{array}{l}\text { 蒸発量 } \\
(\mathrm{cm} / \text { 年) }\end{array}$ & $\begin{array}{l}\text { 蒸 発 量 } \\
\text { 年降水量 }\end{array}$ & $\begin{array}{c}\text { 現在の } \\
\text { 分布 } \\
(\%)\end{array}$ & $\begin{array}{c}\Delta_{\mathrm{T}} \\
+1.4^{\circ} \mathrm{C} \\
(2005 \text { 年 })\end{array}$ & $\begin{array}{c}\text { (予測分布) } \\
+2.2^{\circ} \mathrm{C} \\
(2025 \text { 年 })\end{array}$ & $\begin{array}{c}\text { 完新生の解析 } \\
+1.2^{\circ} \mathrm{C} \\
(4600- \\
6000 \text { 年前 })\end{array}$ & $\begin{array}{c}\text { 最 終間 } \\
\text { 水期 } の \text { 解析 } \\
+2.1^{\circ} \mathrm{C} \\
\text { (12万 } 5 \text { 千年前) }\end{array}$ \\
\hline \multicolumn{2}{|c|}{ 亜北極域ツンドラ帯 } & $28-35$ & $0.42-0.58$ & 19.5 & 8.0 & 3.0 & 13.09 & 9.3 \\
\hline 針＼cjkstart葉 & 樹 林 带 & $35-52.5$ & $0.56-0.71$ & 38.7 & 13.7 & 11.3 & 44.3 & 20.1 \\
\hline 混合 & 林 & $52.5-60$ & $0.66-1.00$ & 7.3 & 19.7 & 15.7 & 8.3 & 34.0 \\
\hline 広 葉 & 樹 林 帯 & $60-85$ & $0.55-1.00$ & 1.1 & 5.6 & 14.5 & 7.5 & 10.9 \\
\hline 森林 ス & テップ帯 & $60-90$ & $1.00-1.22$ & 6.5 & 15.8 & 15.2 & 2.9 & 6.5 \\
\hline ス テ & ッ プ 帯 & $70-100$ & $1.22-2.00$ & 11.2 & 20.3 & 18.8 & 9.4 & 11.0 \\
\hline 半 砂 & 漠带 & $77.5-100$ & $2.00-3.00$ & 157 & 158 & 165 & 146 & 82 \\
\hline 砂 & 漠蒙 & $80-155$ & $3.00-8.00$ & 10.7 & & & 14.0 & 0.2 \\
\hline$\vec{\tau}-g$ & 不確 定 域 & & & 0.0 & 1.1 & 5.0 & 0.0 & 0.0 \\
\hline
\end{tabular}


しかし, 古気候復元資料から $4600 \sim 6000$ 年前の完 新世 (現在よりも約 $1.2^{\circ} \mathrm{C}$ 高かった) と $1.4^{\circ} \mathrm{C}$ 上昇時の予 測データを比較すると, 全般的に高緯度の減少率は 予測よりも小さく, 低緯度での増加の予測は反対に 減少するという結果となっている. 計算値と実況值 (古気候復元值)とのギャップはまだ大きいようであ る.

\section{4. カスピ海の水位変㘯の長期予湘}

1892年から1984年の資料より, カスピ海周辺33地 点の降水量・気温偏差・ボルガ川に流入した流量と カスピ海の水位との相関関係がそれぞれ求められて いる. 図一11はその結果であるが，統計的処理によ りラグ相関が求められており数年後のカスピ海の水 位予測が可能となる7).

图一11によると，降水量と流量・流量と水位とは ともに同時正相関が強いが， 4 年後に降水量と流量 が， 5 年後には流量と水位との相関が正相関から負 相関に変わっている. 流量と水位が再び正相関とな るのは13年後である，このことより，現在の水位は 次第に低下していき，8年後に最低水位となった後, 9 年後から再び上昇に向かうことが予測できる.
しかし，80年代に入ってからの持続的な高温と流 量の増加を考えたとき，単純にはいかないようであ る.

図一 12 は, 古気候復元より全球気温が $1^{\circ} \mathrm{C}$ 上昇 (2000年) したときと， $2{ }^{\circ} \mathrm{C}$ 上昇したとき（2020年） の冬季と夏季の気温，年間降水量を初期值としてボ ルガ川・ドニエプル川・ドン川の流量変化を予測し たものである ${ }^{12)}$.

これらの河川では, 全球的な気候の温暖化に伴い 冬季の流量は 80 年代から増加してる. 图一12による と, 3 つの河川とも冬季の流量の増加と夏季の隇少 が共通している．また，2000年にかけて年間流量は 一定あるいは減少傾向であるが, 2020年にかけては 増加傾向となるようである。ここで, 流量変化には, 気温の上昇により冬季の雪解け量が増える効果が大 きく, 流量変化には年間降水量よりも気温変動の方 がより敏感であるということである。

総合して, カスピ海の水位が今後どのように推移 するかについては图一13に示す12).

図一13は，1988年を初期値としたときの1989年か ら2020年までの水位予想である．実際は，1992年度 も水位の上昇は続いているが, 今後の長期的傾向と

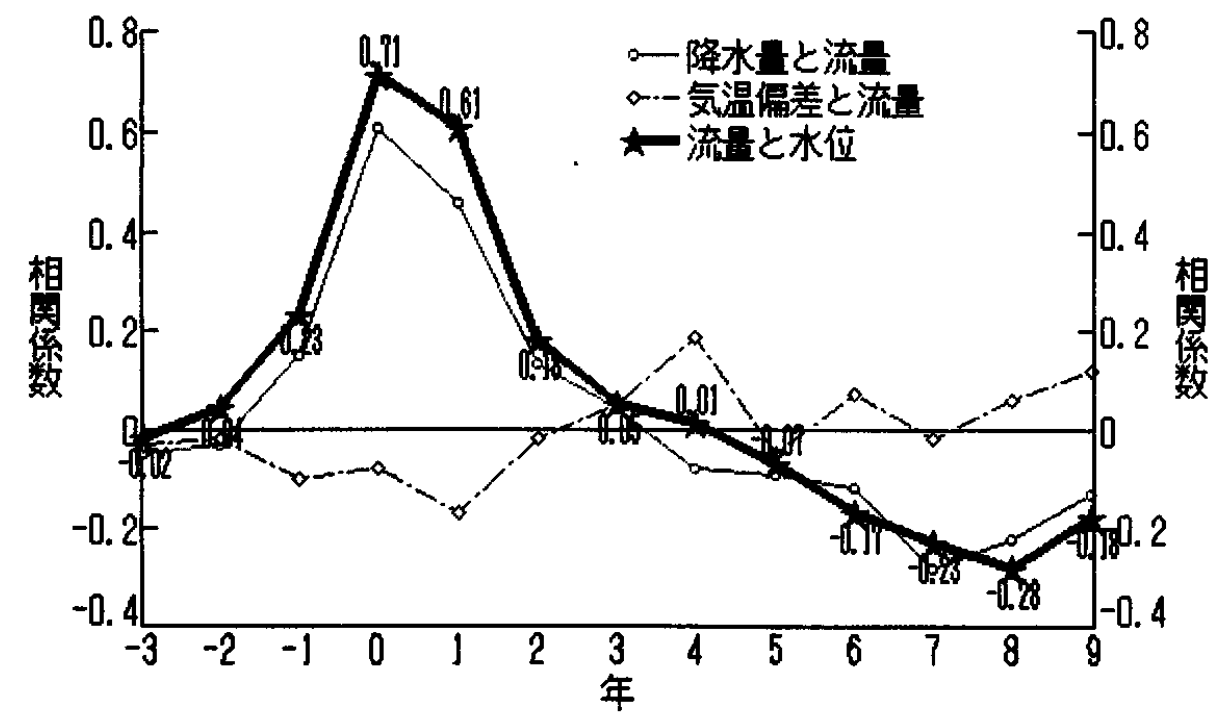

図一11 ボルガ川流城での降水量・気温倨差と流量 との相闍係数, 流量とカスピ海の水位との 相関保数 7 . 
洤䭪 $(\mathrm{mm})$

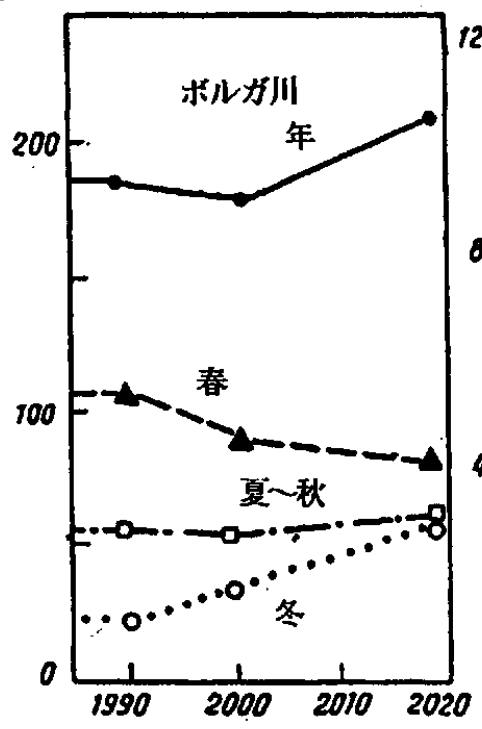

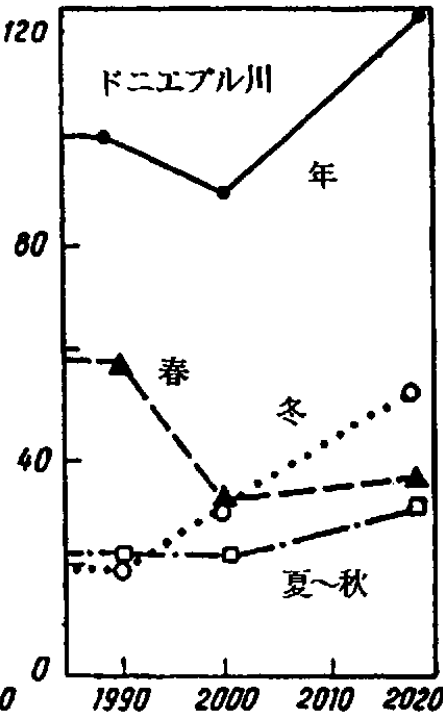

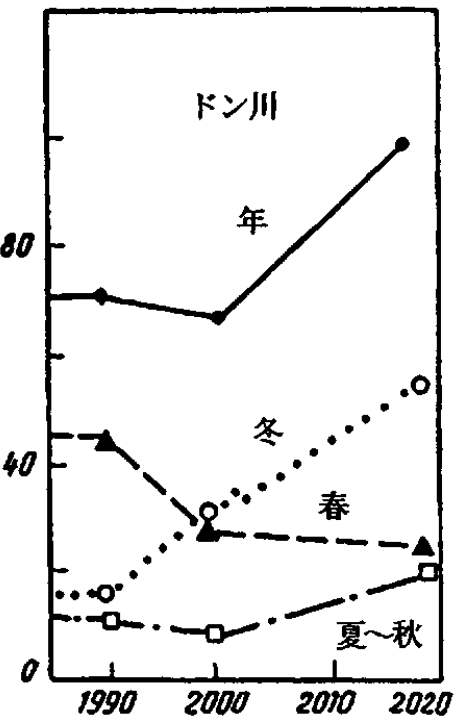

图一12 2000年と2020年の気候变化を古気候から得 元し, ボルガ川, ドニェプル川, ドン川の

流量变化を季節と年間で予測した図 ${ }^{12)}$.

水位

(m)

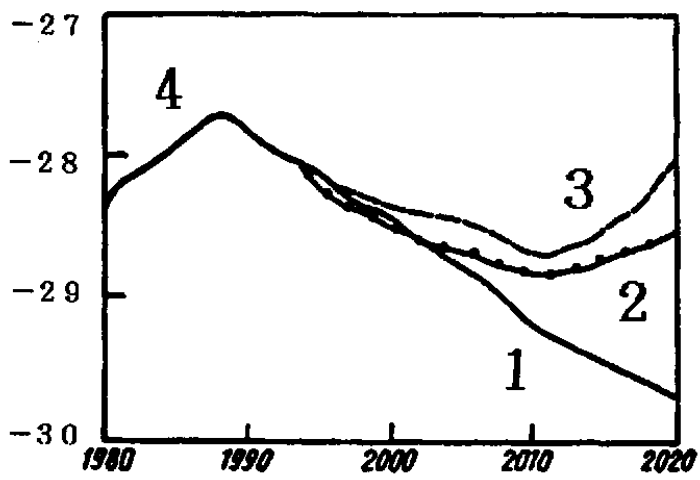

図一13 カスピ海の水位の長期予測（1989 2020 年). 1 は気候条件が一定下, 流域での人間 活動度を取り込んだ場合 2 は人為的な気 候条件下，水文モデルで流量を計算した場 合 3 は古気候の復元から流量を計算した 場合 4 は1988年までの水位の実況値をそ れぞれ示す12).

して参考になると思われる。

手法は, 人為的要因が関係した気候変化時(全球気 温が上昇した時) と現在の気候状態が継続した時に分 類し, 前者は主に古気候復元デー夕を, 後者は流域 での人間活動度が計算に入れられた。
图一13の 1 は, 1880年以降に得られた全ての水バ ランス要素を経験的手法で統計処理し，かつ現在の 気候状態が継続した場合のシナリオである。流域で の経済活動が活発になる結果, 河川流量は減少し水 位も今期間隇少することが予測されている。

图一13の 2 は，水バランス方程式を用いた水文モ デルから流量を計算したものである。蒸発量は気温 と降水量から計算されている。 今世紀末にかけ流量 は急激に滅少しボルガ川での流量は初期值の 8 〜 12\%に減少するが，その後は 2020 年にかけて $15 \%$ まて増加するようである. 特に, 2020年には蒸発量 は $3 \%$ の增加が予測されているが，流域での降水量 は $60 \%$ 増加し水位は上昇傾向となることが予測され ている.

図一13の 3 は，これまで述べてきた古気候復元か ら流量を予測し，水位に換算したものである（図

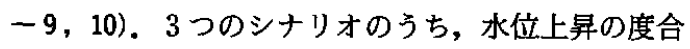
は一番高めに予測されている.

どちらにしても, ロシアの予測資料では今後カス ピ海の水位は現在よりも低下していくことが予測さ れている。

おわりに

ロシアにおけるカスピ海の水位変動は, 周辺の住 
民にとって重大な社会問題となっている，私達もそ の実況を監視していきたいと思う。これまで述べて た要点は以下の通りである.

1. ボルガ川中・上流域での流量の増加が1978年 以降のカスピ海の水位上昇の 1 つの要因と なっている.

2. ヨーロッパロシア周辺での 80 年代に入ってか らの冬季の高温により河川流量が増加した結 果, カスピ海の水位が上昇している。

3 . 気候要因以外にも人工貯水池等による河川流 量の調整，農業適地開拓 (自然改造)も水位上 昇に関係していることが考えられる.

4.カスピ海の水位変動の予測については不確定 要素は多いが, 今後の気温上昇を加味しても 数年間は現状維持か水位低下が予想されてい る.

最後になりましたが，このような機会を与え下さ いました東京都立大学增田先生に感謝します。

\section{参考文献}

1) Блатов А.С., Ведев Д.Л., Косарев А.Н. (1990): О сеишахв Каспийском море, Мет. и Гид., NO. 8. cc. 109 114

2) Борзенкова И.И., Зубаков В.А., лапенис А.Г. (1992): Реконструкции глобального климата теплых зпох прошлого, Мет. и Гид., NO. 8.cc. 25 37

3) Винников К.Я., Лемешко Н.А., Сперанская Н.А. (1990): Влагосодержание почвы и сток внетропической части Северного полушария при глобальном потеплении, Мет. и Гид., NO.3.cc. 5 10

4) Груза Г.В., Ранькова Э.Я. (1991): Вероятиостный прогноз приземной глобальнои температуры воздуха до 2005 г., Мет. и Гид., NO. 4. сc. 95 103
5) Кобак К.И., Кондрашева Н.Ю. (1992): Глобальное потепление и природные зоны, Мет. и Гид., NO. 8. cc. 91 98

6) Лобанов В.В. (1990): Влияние изменений испарения с поверхности каспийского моря на его будуший уровень, Мет. и Гид., NO. 3. cc. 72 78

7) Мешерская А.В., Воробьева Е.К. (1990): Оценка зависимостей между температурно-влажностным режимоми суммарным речным притоком в Каспийское море, Мет. и Гид., NO. 9. сc. 78 86

8) Педь Д.А., Перевозчикова О.И. (1989): О формировании температуры воздуха зимой на Европейской территория СССР, Мет. и Гид., N. 8. cc. $5 \sim 10$

9) Семенов В.А., Алексеева А.К. (1989): Региопальные особениости климатических изменений стока рек CCСР. Мет. и Гид., NO. 9. сc. 91 97

10) Солдатова И.И. (1992): Причины изменения сроков появления льда на Нижней Волге. Мет. и Гид., NO. 2.cc. 82 87

11) Тренин В.А., Добровольский А.А. (1991): Об изменении уровня Каспия, Мет. и Гид., NO. 11. сc. 123 125

12) Шикломанов И.А., Линз Г. (1991): Влияние изменений климата на гидрологию и водкое хозяиство, Мет. и Гиг., NO.4. сc. 51 66

13）森広道 (1990)：ウインターキルの実況監視につ いて, 日本気象学会関西支部例会, No. 52 , PP. 27-34 